ХРОНИКА

DOI: $10.17805 /$ trudy.2018.6.11

\title{
ИТОГИ ХХVII МЕЖДУНАРОДНОЙ НАУЧНОЙ КОНФЕРЕНЦИИ «ШЕКСПИРОВСКИЕ ЧТЕНИЯ 2018»
}

\author{
Н. В. Захаров \\ Московский гуманитарный университет
}

Аннотация: В статье представлен обзор результатов ХXVII Международной научной конференции «Шекспировские чтения 2018», которая проходила в Москве с 24 по 27 сентября 2018 г.

Ключевые слова: Шекспировские чтения; У. Шекспир; Шекспир в России; шекспироведение; шекспиросфера

\section{THE OUTCOMES OF THE 27TH INTERNATIONAL CONFERENCE "SHAKESPEARE READINGS 2018"}

\author{
N. V. Zakharov \\ Moscow University for the Humanities
}

Abstract: The article presents an overview of the results of the International Conference "Shakespeare Readings 2018", which took place in Moscow in September 24-27, 2018.

Keywords: Shakespeare Readings; W. Shakespeare; Shakespeare in Russia; Shakespeare studies; Shakespearean sphere; conferences

В 2018 г. исполняется 400 лет с момента написания оды «Памяти мастера Уильяма Шекспира» (In Remembrance of Master Shakespeare) крестником драматурга Уильямом Давенантом (1606-1668). Давенанту было тогда двенадцать лет, а со смерти Шекспира минуло два года, но любовь, выраженная в его стихах, породила непреходящее преклонение перед памятью Барда:

Beware, delighted poets, when you sing,

To welcome nature in the early spring,

Your numerous feet not tread

The banks of Avon, for each flower

(As it ne'er knew a sun or shower)

Hangs there the pensive head.

\footnotetext{
${ }^{1}$ Конференция была организована при поддержке Российского фонда фундаментальных исследований (проект № 18-012-20073г).
} 
Each Tree, whose thick, and spreading growth hath made,

Rather a Night beneath the Boughs, than Shade,

(Unwilling now to grow)

Looks like the Plume a Captive wears,

Whose rifled Falls are steeped i'th tears

Which from his last rage flow.

The piteous River wept itself away

Long since (Alas!) to such a swift decay;

That reach the Map; and look

If you a River there can spy;

And for a River your mock'd Eye,

Will find a shallow Brook.

Впоследствии У. Давенант сам стал известным драматургом - автором адаптаций шекспировских пьес «Мера за меру» и «Много шума из ничего», «Два знатных родича», «Буря», «Гамлет» и «Юлий Цезарь», автором либретто оперы «Макбет». Он получил звание поэта-лауреата и был возведен в рыцари, став «сэром Уильямом», чем «превзошел» успехи «мастера Шекспира». Однако, пожалуй, самым интересным, что связывает его с великим предшественником, стала легенда о том, что именно Шекспир был его родным отцом. Сам ли Давенант придумал эту историю, злые ли языки оговорили его родителей, но факт ее появления свидетельствует о раннем проявлении шекспировского мифа, напрямую связанного с возникновением культурного признания писателя и дальнейшей эволюцией его литературной репутации.

Сегодня интерес к наследию великого английского драматурга и поэта как никогда велик, во всем мире и в России выходят новые научные монографии о Шекспире, переводы его произведений, появляются театральные и киноверсии его пьес, игровые и научно-популярные фильмы о его судьбе и эпохе.

24-27 сентября 2018 г. Шекспировская комиссия РАН отметила 400-летие «культа Шекспира» большой шекспировской конференцией. В ней участвовали более 70 человек из регионов России и 7 зарубежных исследователей.

XXVII Международная научная конференция «Шекспировские чтения 2018» проводилась Шекспировской комиссией при Научном совете «История мировой культуры» Российской академии наук и Московским гуманитарным университетом при участии Государственного института искусствознания, ГБУК г. Москвы «Музейное объединение “Музей Москвы”» (филиал «Старый Английский двор»), Православного Свято-Тихоновского 
гуманитарного университета, Российского института театрального искусства - ГИТИС, Отделения гуманитарных наук Русской секции Международной академии наук (IAS, Австрия).

В оргкомитет конференции вошли доктор искусствоведения, профессор главный научный сотрудник сектора современного искусства Запада Государственного института искусствознания, заведующий кафедрой истории зарубежного театра Российского института театрального искусства ГИТИС, заслуженный деятель науки РФ, председатель Шекспировской комиссии РАН Алексей Вадимович Бартошевич; доктор философии (PhD), кандидат филологических наук директор Шекспировского центра Института фундаментальных и прикладных исследований МосГУ, ученый секретарь Шекспировской комиссии РАН Николай Владимирович Захаров; кандидат философских наук, секретарь Научного совета «История мировой культуры» РАН Наталья Владимировна Вдовина, а также члены Шекспировской комиссии РАН: кандидат филологических наук доцент кафедры германской филологии Православного Свято-Тихоновского гуманитарного университета Владимир Сергеевич Макаров; кандидат философских наук начальник научно-исследовательского отдела цифровых технологий Института фундаментальных и прикладных исследований МосГУ Борис Николаевич Гайдин; режиссёр театра-студии «Горизонт» Московского городского дома учителя, драматург Виталий Романович Поплавский; доктор культурологии профессор кафедры философии, политологии и культурологии МосГУ Инна Ивановна Лисович; кандидат педагогических наук доцент кафедры лингвистики и межкультурной коммуникации Института иностранных языков Рязанского государственного университета им. С. А. Еселнина Владимир Анатольевич Рогатин; кандидат философских наук доцент кафедры философии Института социально-гуманитарного образования Московского педагогического государственного университета Валерия Сергеевна Флорова.

В каждой области гуманитарных наук разработаны собственные подходы к работе с литературным текстом, в том числе шекспировским. Формат конференции с большим количеством участников позволяет сосредоточиться на общем и различном в том, как представители разных наук подходят к одному и тому же тексту, и дать ответ на вопросы о том: какую роль литературный текст играет в изучении истории и культуры шекспировской Англии и последующих эпох, вплоть до современности; в какой мере могут шекспироведы обогатить свои подходы достижениями широкого спектра наук; могут ли методологически различные исследования одного и того же явления доказать существование единого гуманитарного пространства; насколько полезными междисциплинарные дискуссии могут быть для углубленной разработки методов исследования в отдельных 
Научные труды Московского гуманитарного университета 2018 № 6

гуманитарных науках; и др. Особенно полезным обсуждение междисциплинарных подходов может быть для студентов и аспирантов российских вузов, молодых ученых.

Международные научные конференции «Шекспировские чтения» проводятся по инициативе А. А. Аникста с 1976 года. В конференции принимают участие исследователи Шекспира, английской и мировой культуры XVIXXI веков из вузов России (БашГПУ им. М. Акмуллы, ГИ СПбГПУ, ДВФУ, ДГУ, КГУ, КМТИ им. Г. П. Вишневской, КФУ, МГИМО (У), МГУ, МосГУ, МПГУ, НИУВШЭ, ННГАСУ, ПГК им. А. К. Глазунова, ПензГТУ, ПСТГУ, РАНХиГС, РГГУ, РГИСИ, РГСУ, РГУ, РИТИ - ГИТИС, РХГА, СПбГАИЖСА, СПбГУ, ТВГУ, УГИИ, УРИО, ЮФУ и др.), исследовательских институтов РАН (ИМЛИ РАН, ИНИОН РАН, ИФиП УрО РАН), учреждений Министерства культуры РФ (ГИИ, ГМИИ им. А.С. Пушкина), независимые исследователи, представители зарубежных вузов и научных центров Франции, Республики Беларусь и Украины. Всех их объединяет братская любовь к творческому наследию британского драматурга, осознание его наднационального значения, того, что Ф. М. Достоевский в свое время назвал всемирностью и всечеловечностью А. С. Пушкина.

Конференция открылась в понедельник 24 сентября, в Казённой палате «Старого Английского двора» (ул. Варварка, д. 4а). С приветствием выступил руководитель музея А. Б. Сотин, а модератор заседания Н. В. Захаров (МосГУ, Москва) обозначил новые «Перспективы изучения творческого наследия У. Шекспира». Далее последовали сразу два доклада представителей шекспировской школы МГУ: «Слово Горацио, или «Гамлет» как психодрама Н. Э. Микеладзе и доклад "“Смерть его не шелохнет упрека": мистериальные истоки “сцены заговора" против Гамлета» Д. А. Иванова. В. С. Макаров (ПСТГУ, Москва) назвал свой доклад «Шекспир после Барда: контекст, усложнение и всемирность».

Конференция продолжилась в Зеркальном зале Государственного института искусствознания (ГИИ) (Козицкий пер., д. 5) секцией «Проблемы изучения шекспировских переводов. Ее модератором выступила Е. А. Первушина (ДВФУ, Владивосток), а ее доклад был посвящен «Русским переводам комедии Шекспира “Love's Labour's Lost”». Тему переводов продолжили А. А. Евдокимов (МГУ, Москва) с докладом ««Ромео и Джульетта» в ранних русских переводах», Е. М. Масленникова (ТвГУ, Тверь) рассказал про «Эвфемизмы в произведениях У. Шекспира: скрытые подтексты», студентка из Владивостока Е. О. Кудряшова (ДВФУ) рассказала «О переводах сонетов Шекспира А. Ю. Милитарева».

«Просодическим особенностям имен персонажей в русских переводах Шекспира» был посвящен доклад М. М. Савченко (Париж, Франция); темой доклада А. В. Калашникова (НИУ ВШЭ, Москва) стали «Характеристические 
имена мастеровых в переводах на русский язык комедии «Сон в летнюю ночь». Национальным особенностям восприятия драматурга были посвящены доклады исследователей из КФУ (Казань): «Шекспир и тюркские литературы: к постановке проблемы» Р. Ф. Бекметова и «Шекспир в переводах Наки Исанбета: «Гамлет» в татарском контексте» А. М. Саяповой.

Работу конференции в первый день продолжил Круглый стол по проекту «Разработка и внедрение в открытом доступе онлайн-программы сравнительного тезаурусного анализа русских переводов произведений У. Шекспира» (www.shakespearecorpus.ru), осуществляемого при поддержке РФФИ (проект № 17-04-12038в). Свои доклады представили три исследователя из МосГУ (модератор - Б. Н. Гайдин). Он и прочитал первый доклад “"Троил и Крессида" У. Шекспира в русских переводах: сравнительный тезаурусный анализ». И. И. Лисович представила доклад “"Life’s but a walking shadow, a poor player": проблема вариативности перевода метафоры-концепта пьесы «Макбет»У. Шекспира», а Н. В. Захаров выступил на тему «Сравнительный анализ русских переводов первой сцены “Меры за меру” У. Шекспира». Завершил работу Круглова стола большой доклад В. С. Макаров (ПСТГУ, Москва) «Ранние комедии Шекспира: анализ переводческих стратегий при помощи платформы VVV».

Работа первого дня конференции завершилась просмотром в «Музее московского образования» (Вишняковский пер., д. 12. стр. 1) обновленную версию спектакля «Отелло, венецианский мавр» (реж. В. Р. Поплавский). Театр-студия «Горизонт» Московского городского дома учителя представит трагедии У. Шекспира в классическом переводе Б. Л. Пастернака.

Вторник 25 сентября, конференция продолжила свою работу в ГИИ секциями «Шекспир на экране и сцене», «Методические аспекты изучения У. Шекспира в школе и вузе»; «Шекспир в музыке»; «Русский Шекспир». С докладами выступили: В. Р. Поплавский (МГДУ, Москва) «Несыгранные Гамлеты»; Е. Н. Гринина (СПбГАИЖСА, Санкт-Петербург) «Интерпретации пьес У. Шекспира на сцене Санкт-Петербургского академического драматического театра им. В. Ф. Комиссаржевской в конце XX - начале XXI века»; Е. Р. Меньшикова (НИК, Москва) «Миф как искупительная жертва, или молчание ягнят шекспировской трагедии (драматургическая камера-обскура XVI века на сцене XXI века)»; Н. С. Шабалина (АРБ им. А. Я. Вагановой, Санкт-Петербург) “"Гамлет” в отечественных фильмах-балетах: синтез балетной пластики и киноязыка»; Ю. А. Фомина (МосГУ, Москва) «Мюзикл «Ромео и Джульетта» Жерара Пресгюрвика: интерпретация сюжета и образа в неоромантической стилистике»; В. А. Рогатин (РГУ, Рязань) «Активизация финансовой лексики и актуализация текстов Шекспира для студентов»; М. А. Аристова (ИСРО РАО, Москва) «Шекспир на уроках литературы в шко- 
Научные труды Московского гуманитарного университета 2018 № 6

ле: современные читательские практики»; Т. В. Боровикова (ДШИ № 5, Томилино), А. В. Калашников (НИУ ВШЭ, Москва) «Шекспир в скандинавской музыке»; М. Я. Куклинская (КМТИ им. Г. П. Вишневской) «Три «Отелло»: Дж. Верди, А. Бойто, У. Шекспир»; О. В. Никифорова (ПГК им. А. К. Глазунова, Петрозаводск) «Черты постмодернизма в «Песнях Ариэля» Д. Н. Смирнова»; Е. М. Тараканова (ГИИ, Москва) «Асафьев читает Гервинуса»; Б. Н. Гайдин (МосГУ, Москва) «Творчество У. Шекспира в русской рок-музыке: национальное и глобальное»; А. А. Тевяшев (МГУ, Москва) «К проблеме шекспировского текста в комедии А. С. Грибоедова "Горе от ума"»; А. М. Бенькович (МГУ, Москва) «Шекспировские параллели в драме А. Н. Островского “Гроза”»; Д. Н. Жаткин, А. А. Рябова (ПензГТУ, Пенза) «Шекспир в творчестве Максимилиана Волошина»; М. Ю. Савельева (ЦГО НАНУ, Киев, Украина) «Лев Шестов и “шекспировский вопрос"».

Работа второго дня конференции завершилась Круглым столом «Шекспир и “Шекспиры”». В рамках которого состоялось обсуждение статьи Д. А. Иванова, В. С. Макарова, С. Д. Радлова «Шекспир и “шекспиры”», вышедшей в № 8 журнала «Иностранная литература» за 2018 г. (см.: Иванов, Макаров, Радлов, 2018: Электр. ресурс).

Всю среду 26 сентября конференция была посвящена самой крупной секции «Шекспир и его современники: тексты и интерпретации XVI-XVIII вв.» (модераторы - Е. В. Халтрин-Халтурина, В. С. Макаров). С докладами выступили: Е. В. Халтрин-Халтурина (ИМЛИ РАН, Москва) «Антропоморфные пейзажи в литературе (на материале Эдмунда Спенсера)»; Е. Н. Чернозёмова (МПГУ, Москва) «Функция образа монарха в становлении ренессансной системы драматических жанров (Тамерлан Марло и Александр Македонский Лили)»; Н. И. Прозорова (КГУ, Калуга) «Понятие театральности и драматургия Шекспира»; А. В. Титова (РГУ, Рязань) «Миф о Фениксе: шекспировская трактовка»; Н. В. Шипилова (ПСТГУ, Москва) «Образ вертограда в шекспировской драматургии и его средневековые истоки»; Н. С. Зелезинская (БГУ, Минск, Беларусь) «Мотив самоубийства в творчестве У. Шекспира»; В. А. Ковалёв (СПбГУП, Санкт-Петербург) «Творчество Шекспира и рождение неоримского дискурса в Англии»; К. Е. Крылов (независимый исследователь, Санкт-Петербург), Е. Е. Крылова (независимый исследователь, Санкт-Петербург) «Мифологические образы в пьесы У. Шекспира “Сон в летнюю ночь"»; В. А. Ковалёв (СПбГУП, Санкт-Петербург) «Перейти на светлую сторону: магия на службе положительных героев Шекспира в контексте ренессансных магических представлений».

Завершился третий день заседаний Чтений проведением «Семинара журнала Valla» (модератор - M. В. Елифёрова). Свои доклады представили: M. В. Елифёрова (журнал Valla, Москва), А. В. Титова (РГУ, Рязань) «“Школа 
Венеры”», М. М. Фиалко (РХГА, Санкт-Петербург) «"Во всем этом огромном колоссе не было и одной унции живой плоти"»: розенкрейцерский образ из сатир Боккалини и "Крокодил" Сен-Мартена»; Я. Ю. Старцев (ИФиП УрО РАН, Екатеринбург) «Авторство “Любовных стансов королевы Наваррской”: опыт стилометрического анализа»; В. С. Флорова (МПГУ, Москва) «Метафора еды-любви в сонетах Шекспира».

На этом работа конференции в уютных стенах Государственного института искусствознания завершилась.

27 сентября - последний четвертый день работы конференции по сложившейся традиции перекочевал на территорию Московского гуманитарного университета (МосГУ). Второе пленарное заседание (модератор Н. В. Захаров) открыли доклады В. А. Лукова (МосГУ, Москва) «Шекспиросфера как социальная реальность XXI века» и И. Г. Пехович (Театр на Таганке, Москва) «Загадки Шейлока».

Завершили работу конференции два заседания секции «Шекспир в литературе и культуре XIX-XXI вв.» (модераторы - И. И. Лисович и Е. Н. Шапинская). С докладами выступили: Л. Л. Корнеева (НГУ им. Н. В. Гоголя, Нежин, Украина) «"Ромео и Джульетта” и «эффект Вертера»: к проблеме интерпретации шекспировской трагедии»; А. А. Юрьев (РГИСИ, Санкт-Петербург) «“Борьба за престол” Хенрика Ибсена и исторические драмы Шекспира»; Е. А. Шевченко (РГГУ, Москва) «Диккенс и викторианский Шекспир: формирование культа и приемы “присвоения" Барда»; М. П. Кизима (МГИМО (У) МИД России, Москва) «Шекспир и становление современной американской драматургии: диалог с Шекспиром в творчестве Лилиан Хеллман»; Л. С. Артемьева (ННГУ, Нижний Новгород) «Шекспировские аллюзии в переводе-адаптации Б. Эндрюса драмы “Три сестры” А. П. Чехова»; Е. Н. Шапинская (РГУФКСМиТ, Москва) ““Гамлет” в зеркале абсурда: пьеса Т. Стоппарда “Розенкранц и Гильденстерн мертвы” как опыт деконструкции»; М. В. Маркова (РГГУ, Москва) «Титания в дирижабле: Шекспир и стимпанк»; Е. В. Тихомирова (КНЛУ, Киев, Украина) «Шекспировские мотивы в литературе фэнтези»; Д. В. Тябина (КФУ, Казань) «Образ Елизаветы I в культуре XX века»; С. П. Никольская (ННГАСУ, Нижний Новгород) «“Here’s snip and nip and cut and slish and slash": понятие «разрез» в искусстве и дизайне».

XXVII Международная научная конференция «Шекспировские чтения 2018» (Shakespeare Readings 2018) стала одной из наиболее представительных среди тех, которые проводились за последние десять лет. Она охватила практически все сферы современного гуманитарного знания: литература народов зарубежных стран и Российской Федерации, теорию и историю литературы, текстологию, журналистику, театроведение, музыковедение, изобразительное искусство, киноведении, история философии, социальная 
Научные труды Московского гуманитарного университета 2018 № 6

философия, философия культуры, философская антропология, философия религии и религиоведение, история политической науки и политической мысли, мировая политика, региональные и этнополитические процессы, социология культуры, методология комплексного изучения проблем обучения и воспитания и информационные технологии в образовании, электронные и дистанционные образовательные технологии.

Участники особенно отметили удачно выбранный формат проведения конференции, а именно разделение ее на пленарные и секционные заседания и круглые столы. Каждый может выбрать заседание в соответствии со своими научными интересами, записаться на определенное время для их посещения, на таких заседаниях, как правило, было большее количество исследователей, преподавателей вузов и школ, представителей студенчества. Все они принимали активное участие как в общих дискуссиях, так и в кулуарных беседах, что, несомненно, способствовало установлению новых научных контактов, деятельному и живому общению ученых.

Примечательно, что после юбилейных конференций 2014 и 2018 годов шекспировский научный марафон не только ни сбавил темп, но и поднял условную планку требований к качеству подаваемых заявок, докладов и статей участников «Шекспировских чтений 2018». Удачно, что только две секции работали параллельно друг другу. Шесть из семи иностранных гостей в этом году прибыли из стран ближнего зарубежья: Белоруссии и Украины. В этом смысле Шекспир нас объединяет, несмотря на все сложности современной политической конъюнктуры во всем мире. Конференция собрала представителей из многих регионов нашей страны, особенно радует, что интерес к изучению Шекспира из года в год растет в молодежной среде.

На конференции был заявлен вектор прошекспировского дискурса в изучении «шекспировского вопроса», дан критический анализ конспирологических теорий, фантастических гипотез, псевдонаучных «открытий» и прочей антишекспировской ереси, которая с особой силой разрослась на территории бывшего Советского Союза после его распада. Многие участники конференции видят перспективы развития отечественного и всемирного шекспироведения в развитии «постбардовского» подхода, когда драматург воспринимается не как гениальный небожитель, затмевающий собой современников, а «как равноправный соучастник многоуровневого литературного процесса в Англии рубежа XVI-XVII веков» (Макаров, 2018, частная корреспонденция), и в использовании методики тезаурусного анализа (см. Луков, Луков, 2008 и 2013), который набирает все большее число последователей в отечественной гуманитаристике, актуализируя такие понятия, как культ Шекспира шекспиризм, шекспиризация, шекспиризм, шекспиросфера и пр. (см.: Луков, Захаров, Луков, Гайдин, 2012: Электр. ресурс; Лисо- 
вич, Макаров, 2014: 264-282; Захаров, 2015: 193-210; его же, 2016: 263-270; Макаров, Захаров, Гайдин, 2016: 275-302).

К конференции были изданы программа и сборник аннотаций докладов участников конференции «Шекспировские чтения 2018» (см.: XXVII Шекспировские чтения, 2018) на русском и английском языках, они опубликованы и розданы участником, а также доступны на сайте конференции. Видеозапись конференции «Шекспировские чтения 2018» (cм.: http://www. rus-shake.ru/file.php/id/f14466/name/Shakespeare-Readings-2018-Program. pdf) размещена на видеохостинге «YouTube» по адресу:

https://www.youtube.com/channel/UCt8KFWBJm2ohOb9wtYKSp9w/ videos?sort=dd\&view=0\&shelf_id=0 (более 22 часов видеоматериалов).

Конференция получила широкое освещение в российских и международных печатных и электронных СМИ.

\section{СПИСОК ЛИТЕРАТУРЫ}

XXVII Шекспировские чтения 2018 (27th Shakespeare Readings 2018) (2018) : Сборник аннотаций докладов. М. : Изд-во Моск. гуманит. ун-та. 186 с.

Захаров, Н. В. (2015) Шекспир между фактом и воображением: виртуальная шекспиросфера и массовые открытые онлайн-курсы (МООК) // Воображение и факт в конструировании художественных и виртуальных миров шекспировской Англии : сборник научных статей / отв. ред. и сост. И. И. Лисович; ред.: В. С. Макаров, Б. Н. Гайдин. М. : Изд-во Моск. гуманит.унта, С. 193-210.

Захаров, Н. В. (2016) Портретные изображения Шекспира в виртуальной шекспиросфере // Знание. Понимание. Умение. № 1. С. 263-270.

Иванов, Д. А., Макаров, В. С., Радлов, С. Д. (2018) Шекспир и “шекспиры” [Электронный ресурс] // Иностранная литература. № 8. URL: https://goo.gl/ jNocKK (дата обращения: 07.09.2018)

Лисович, И. И., Макаров, В. С. (2014) Научно-исследовательский проект «виртуальная шекспиросфера: трансформации шекспировского мифа в современной культуре» // Знание. Понимание. Умение. № 2. С. 264-282.

Луков В. А., Захаров Н. В., Луков Вл. А., Гайдин Б. Н. (2012) Шекспиросфера (Шекспир, его современники, его эпоха в культуре повседневности) [Электронный ресурс] // Информационный гуманитарный портал «Знание. Понимание. Умение». № 3 (май — июнь). URL: http://www.zpu-journal.ru/ezpu/2012/3/Lukov Zakharov Lukov Gaydin Shakespeare-sphere/ (дата обращения: 06.07.2013)

Луков, Вал. А., Луков, Вл. А. (2008) Тезаурусы: Субъектная организация гуманитарного знания. М. : Изд-во Национального института бизнеса. 784 с.

Луков, Вал. А., Луков, Вл. А. (2013) Тезаурусы II: Тезаурусный подход к 
пониманию человека и его мира. М. : Изд-во Национального ин-та бизнеса. $640 \mathrm{c}$.

Макаров, В. С. (2018) Частная корреспонденция (дата обращения: 13.11.2018).

Макаров, В. С., Захаров, Н. В., Гайдин, Б. Н. (2016) Шекспиросфера в год четырехсотлетия бессмертия поэта // Знание. Понимание. Умение. № 4. C. 275-302. DOI: 10.17805/zpu.2016.4.24.

Дата поступления: 23.10.2018 2.

Захаров Николай Владимирович - доктор философии (PhD), кандидат филологических наук, директор Шекспировского центра Института фундаментальных и прикладных исследований Московского гуманитарного университета, академик Международной академии наук (IAS, Инсбрук, Австрия), ученый секретарь Шекспировской комиссии РАН. Адрес: 111395, Россия, г. Москва, ул. Юности, 5, корп. 6. Тел.: +7 (499) 374-75-95. Эл. адрес: nikoltine@yandex.ru

Zakharov Nikolay Vladimirovich, PhD, Candidate of Philology; Director, Shakespeare Center, Institute of Fundamental and Applied Studies, Moscow University for the Humanities; full member, International Academy of Science (Innsbruck, Austria); Academic Secretary, Shakespeare Committee, Russian Academy of Sciences. Postal address: Bldg. 6, 5 Yunosti St., 111395 Moscow, Russian Federation. Tel.: +7 (499) 374-75-95. E-mail: nikoltine@yandex.ru

\section{Для цитирования:}

Захаров Н. В. Итоги XXVII Международной научной конференции «Шекспировские чтения 2018» [Электронный ресурс] // Научные труды Московского гуманитарного университета. 2018. № 6. URL: http://journals.mosgu. ru/trudy/article/view/842 (дата обращения: дд.мм.гг.). DOI: 10.17805/ trudy.2018.6.11 